\title{
Perceived Skills and Employability of Senior High School Graduates: Basis for Youth Employment Policy
}

\author{
Imelda G. Carada, John Vincent C. Aliazas, Lucila C. Palacio, \& Christian Maria Amor C. Palacio* \\ College of Teacher Education, Laguna State Polytechnic University San Pablo City, Laguna, 4000 \\ Philippines
}

\begin{abstract}
After summer break, the majority of high school graduates in the Philippines enrolled in college. On the other hand, not everyone is cut out for collegiate life after graduating from high school. School has become a nuisance or a cause of irritation for some. Others have expressed dissatisfaction with it. Those who have earned their degree may wish to take a sabbatical before returning to school full-time. Some high school graduates choose to work rather than further their education due to financial concerns. The purpose of this study was to determine the extent to which manifestations influence senior high school graduates' perceived skills and employability. In this study, 324 senior high school graduates from San Pablo City, Laguna, Philippines were polled. Multiple regression analysis was used to uncover key predictors of senior high school graduates' employability. According to the findings, respondents demonstrated a high level of cognitive, technical, and emotional skills. Similarly, senior high school graduates were rated as having a high likelihood of employment. Furthermore, there was a moderate to strong correlation between variables. Finally, technical and emotional skills were identified as key predictors of employability among senior high school graduates. The findings served as the foundation for future youth employment policies.
\end{abstract}

Keywords: perceived skills, employability, senior high school

\section{Introduction}

A variety of educational innovations have occurred in the Philippines' elementary and secondary school systems over the years. Since 1945, there have been three adjustments to the elementary curriculum and four to the secondary curriculum before the $\mathrm{K}-12$ curriculum was developed. The number of school years in basic education in the Philippines was raised from 10 to 12 due to the government's 2013 mandate under Republic Act 10533 to strengthen the country's basic education. The Department of Education announced that the improved curriculum would provide Senior High School (SHS) graduates "with the required competencies, skills, and values for both lifelong learning and employment" as part of the K12 program legislation in the country. Since the two extra years would have given students more experience in college life, they would have also been better prepared to start their own business or land a job without having a college degree. There are work immersion programs for high school seniors, specifically for grade 12 , to help them familiarize themselves with the workplace and the nature of their future jobs and apply what they've learned in class to their future careers (Arturo \& Arturo, 2020). Graduates of senior high school programs have the basic academic skills, creative thinking skills, interpersonal skills, and personal characteristics and attitudes needed to succeed in the workplace.

However, according to the study conducted by Philippine Business for Education (2018), only $20 \%$ of 70 of the country's leading companies across all sectors in the country were inclined to hire senior high school graduates. It was due to worries about their employment preparation, despite the fact that the majority of senior high school graduates have stated a desire to continue their education. In addition, 1 out of 5 companies is ready to hire if hiring policies are aligned with it. But almost every company policy only accepts job applicants with at least two years of a college education; most employers are still stuck in the idea of hiring only college graduates, thus discriminating against senior high school graduates (Cabrera, 2018). This was supported by the Philippine Institute for Development Studies (PIDS, 2021) claimed their study, which began in 2018, found that senior high school graduates had difficulty integrating into the labor 
market, with 22 of the 26 employers surveyed believing they lacked adequate job readiness. Despite this, twenty-four employers expressed an interest in hiring senior high school graduates on the condition that they demonstrate specialized skills, boost on-the-job training hours, and limit them to entry-level roles (BusinessWorld Online, 2021). With this, we could see that the promotion of the Department of Education about senior high school graduates as "employable" could be misleading. And even though our senior high school graduates are fit with the necessary skills and knowledge to enter the workforce, it will be quite impossible for them to do so because of application constraints.

The Department of Education has expanded the number of hours available for job study in the senior high school program from 80 to 230 . The education sector and industry are currently reviewing the K-12 curriculum. Other agencies are looking into how senior high school graduates' employment prospects might be improved. However, due to Covid-19, the unemployment rate in the Philippines grew from 5.1\% in 2019 to $8.8 \%$ in 2020. Almost 4.2 million Filipinos lost their jobs, while 3 million were temporarily terminated and about 4 million were reduced to flexible working hours (PSA, 2021). The pandemic has a long-term impact on employment. Simply said, even when the economy has begun to recover again, this transient significant shock to the economy may result in a consistently lower employment rate (Bird, 2021). As a result of the pandemic, many jobs have been re-allocated across industries. While job losses have occurred in a variety of industries, those that rely on personal contact, such as lodging, food services, transportation, and recreational activities, have been particularly hard hit. Conversely, businesses that absorb a smaller proportion of workers, such as communications and technology, as well as some higher-skilled service sectors, recover quickly and produce positive job creation. Eventually, when the economic sector fully opens, it will be flooded by new graduates and experienced applicants. These applicants have the edge over senior high school graduates (Mocon-Ciriaco, 2018). Consequently, there will be a lower chance for senior high school graduates to get hired (CEICdata.com, 2018). We still have a long way to go before realizing the full potential of the country's senior high-school curriculum. The goal, however, can be accomplished only if the Department of Education and other stakeholders make time to validate the findings of studies conducted on the senior high school curriculum (Cecilio, 2019).

As a result, the goal of this research is to determine how senior high school graduates in San Pablo would like to enter the labor force. The senior high-school program was implemented with the goal of making all graduates productive and employable. Furthermore, this study looks at the relationship between senior high school skills and later job success. Finally, the study's findings will form the basis for a policy proposal targeted at effectively preparing students to be competent and ready to work, hence increasing youth employment.

\section{Literature Review}

\subsection{Personnel Selection}

Personnel selection is a widely used concept in psychology that refers to decision-making to predict the future performance of potential applicants within the company. One of the many studies conducted about personnel selection was by Salgado (2017). He summarized the operational validity of commonly used selection procedures. He created the best combinations of these procedures to predict and explain over $60 \%$ of job performance variance based on individual differences. Hence, strengthens the idea of how personnel selection helps human resources determine who among the job applicants is the most appropriate for a specific position through various assessment procedures. Likewise, in this study, the concept of personnel selection will guide the researcher to understand how managers and or human resources may influence the employment success of the applicants with their decisions based on the result of assessment procedures (Moscoso et al., 2017). But since, there is no distinct instrument that can fully evaluate an applicant. Therefore, the development of the selection procedures, which is the basis for hiring, is grounded on varied and indefinite attributes.

\subsection{Attribution Theory}

Attribution theory explains how people make sense of their world by attributing life events to one's dispositions or environmental characteristics. Heider (1958; Manusov \& Spitzberg, 2008) argues that the purpose of attribution theory is to make people understand the reasons and causes of events. For instance, a 
person denied a position should analyze what leads to such a situation and help them cope for the next job application. In this study, the employment factors gathered by Castro (2014), such as the applicant credentials, job-relevant characteristics, and school/HEI quality, will serve as the attributes for employment success. Moreover, Orbeta Jr. et al. (2018) define employment success as determined through position offering and preconditions. Using attribution theory in companies is beneficial because it can assist managers in better understanding some of the factors that contribute to employee behavior and can support employees in better experiencing their thinking of their behaviors.

\subsection{Career Development and Systems Theory}

According to Patton and McMahon (2014), studying the individual and practitioner systems that drive career development and advice is important. Career development investigates strategies for enhancing one's professional progress, career trajectory, and a general sense of well-being at work. In particular, it highlights three systems that impact the substance of individuals' professional development (interpersonal, social, environmental/societal). Understanding career development theory can be a helpful first step in identifying the basic values, abilities, weaknesses, and the direction an individual wants to take (Conley et al., 2011). Practitioners find themes and locations that suggest gaps or potential hurdles overcome as individuals narrate their systems from their professional life. Beginning with a worldview expressed by individuals through the sharing of their work narratives and moving through the stages of career coaching, both discuss and co-construct interpretations that characterize the subsequent stages of career coaching. Other career development theories or interdisciplinary theories can be included in co-constructed future stages to advise counseling for continued professional growth (Lovasz, 2016).

\section{Objectives of The Study}

This study aimed to know the perceived skills as significant predictors of employability among senior high school graduates. Specifically, it sought to answer the following questions:

3.1. To what extent do the respondents describe their perception of senior high school graduates' skills in terms of cognitive, technical, and emotional skills?

3.2. What is the mean perception of the respondents on employability of senior high school graduates?

3.3. Is there a significant relationship between perceived skills and employability of senior high school graduates?

3.4. Do the perceived skills parameters singly or in combination predicts senior high school graduates' employability?

\section{Methodology}

\subsection{Research design}

An investigation into the relationship between perceived skills and employability of Senior High School graduates will be conducted in this study using a descriptive-correlational approach to data collection. Furthermore, because this study design is dependent on the participants' perception, observation, or interactions, this study will gather and describe the mean perception of the participants using a survey. The researchers established a link between variables and identified significant predictors of senior high school graduates' employability based on the gathered data.

\subsection{Respondents}

There are 324 Senior High School graduates in San Pablo City, Laguna, in the Philippines, who took part in this study. The use of purposive non-probability sampling was employed in order to reach the desired number of responses (95\% response rate) from the target population. This sampling technique enables researchers to select responders from the general community randomly. The summary of the distribution of the profile of the respondents is elicited in table 1 below. 
Imelda G. Carada et./al Perceived Skills and Employability of Senior High School Graduates: Basis for Youth Employment Policy

Table 1. Distribution of the Respondents

\begin{tabular}{|c|c|c|c|}
\hline & Demographic & $F$ & $\%$ \\
\hline \multirow{4}{*}{$\begin{array}{l}\text { Year } \\
\text { Graduated }\end{array}$} & 2018 & 57 & 17.6 \\
\hline & 2019 & 68 & 21.0 \\
\hline & 2020 & 50 & 15.4 \\
\hline & 2021 & 149 & 46.0 \\
\hline \multirow[t]{2}{*}{ Track } & Academic & 239 & 73.8 \\
\hline & Technical-Vocational-Livelihood & 85 & 26.2 \\
\hline \multirow[t]{8}{*}{ Strand } & Accountancy, Business and Management (ABM) & 52 & 16.0 \\
\hline & Humanities and Social Sciences (HUMSS) & 69 & 21.3 \\
\hline & $\begin{array}{l}\text { Science, Technology, Engineering and Mathematics } \\
\text { (STEM) }\end{array}$ & 79 & 24.4 \\
\hline & General Academic Strand (GAS) & 36 & 11.1 \\
\hline & Agri-Fishery Arts (AFA) & 38 & 11.7 \\
\hline & Home Economics (HE) & 22 & 6.8 \\
\hline & Industrial Arts (IA) & 28 & 8.6 \\
\hline & Information and Communication Technology (ICT) & 52 & 16.0 \\
\hline \multirow{8}{*}{$\begin{array}{l}\text { Type of } \\
\text { Industry }\end{array}$} & Agriculture and Fishery & 15 & 4.6 \\
\hline & Computer and Telecommunication Industry & 67 & 20.7 \\
\hline & Construction Industry & 27 & 8.3 \\
\hline & Education Industry & 84 & 25.9 \\
\hline & Food and Manufacturing Industry & 66 & 20.4 \\
\hline & Pharmaceutical Industry & 28 & 8.6 \\
\hline & Transport Industry & 27 & 8.3 \\
\hline & Others & 10 & 3.1 \\
\hline
\end{tabular}

According to the data reported in Table 1, most respondents (46\%) were graduates of the class of 2021. Similarly, the vast majority (73.8\%) were graduates with courses in the Academic track, particularly in the STEM strand $(24.4 \%)$. The academic track is a program intended for students who have made the decision to pursue a college education. The Academic track in senior high school is divided into degree-specific courses, with the goal of preparing students for more advanced university courses in the future (TuominenSoini et al., 2012). The majority of those who answered the survey questions were currently employed in the food and manufacturing industry (20.4\%), the computer and telecommunications industry (20.7\%), and the education industry (25.9\%). Remote employment became the norm because of a global pandemic that forced innovative ways to keep the system running. Some companies embrace the remote work model and will continue to use it full-time in 2021, while others expect to return to on-site work. The change to remote work, on the other hand, taught them a lot about what it takes to be a valued employee in the new normal (Omoth, 2020). According to the study of Orbeta Jr \& Potestad (2020), their findings suggest that only a tiny percentage (just over 20\%) enter the job force and that the majority (more than $70 \%$ ) continue their schooling. The estimates reveal a mixed picture of labor market results, with senior high school graduates sometimes outperforming their classmates and sometimes underperforming them. Given the expressed and demonstrated predisposition of senior high school graduates to pursue their dreams rather than enter the job market, these findings imply that the employment and entrepreneurial objectives of senior high school should be re-examined.

\subsection{Instruments}

The instrument used in the study was a researcher-made questionnaire. Content validity was applied to all indicators for perceived skills (cognitive, technical, emotional) and employability of senior high school graduates. Experts in education, research and statistics, measurement, and evaluation were consulted. Internal consistency and reliability were validated using Cronbach's Alpha scale at an acceptable to excellent level (see Table 2.). 


\subsection{Data Collection}

Due to Covid-19 restrictions, data was collected via online surveys encoded in web-based software. The survey link was then emailed to the target sample. Proper research ethical standards and protocols were rigorously followed by providing respondents with an informed consent form to express their understanding of the study's purposes. The confidentiality and anonymity of their response were highly valued. Only the researcher who analyzed the data had access to sensitive information about the respondents, such as names and email addresses.

\subsection{Data Analysis}

In this study, descriptive statistics such as mean and standard deviation was used to identify data variation (Wan et al., 2014) and respondent's' perception on the perceived skills and employability of senior high school graduates. Then, Pearson correlation coefficient was also used to test if a significant relationship exists between variables (Leech et al., 2014). Furthermore, regression analysis was used to understand better and uncover key predictors of senior high school graduates' employability, which was the focus of this study.

\section{Results and Discussion}

Table 2. Mean, Standard Deviation, Cronbach's Alpha, and Correlations among the Study Variables

\begin{tabular}{|l|c|c|c|c|}
\hline \multicolumn{1}{|c|}{ Variables } & $\mathbf{1}$ & $\mathbf{2}$ & $\mathbf{3}$ & $\mathbf{4}$ \\
\hline 1. Cognitive Skills & - & & & \\
\hline 2. Technical Skills & $0.757^{* *}$ & - & & \\
\hline 3. Emotional Skills & $0.762^{* *}$ & $0.734^{* *}$ & - & \\
\hline 4. Employability & $0.531^{* *}$ & $0.576^{* *}$ & $0.537^{* *}$ & - \\
\hline Mean & 3.35 & 3.33 & 3.36 & 3.22 \\
\hline SD & 0.495 & 0.459 & 0.479 & 0.509 \\
\hline Cronbach's Alpha & 0.919 & 0.909 & 0.917 & 0.864 \\
\hline
\end{tabular}

$N=324 * *$ Correlation is significant at 0.01 level (2-tailed)

All perceived skills variables had higher mean values in Table 2, with emotional skills $(\mathrm{M}=3.36, \mathrm{SD}=0.479)$ having the highest mean and variability of all the categories. A similar pattern emerges in the results, which reveal that respondents' perceptions of their cognitive $(\mathrm{M}=3.35 \mathrm{SD}=0.495)$ and technical skills $(\mathrm{M}=3.33$, $\mathrm{SD}=0.459)$ are strongly exhibited. The employability of senior high school graduates $(\mathrm{M}=3.22, \mathrm{SD}=0.509)$ was determined by obtaining mean values suggesting that senior high school graduates are likely to find work after graduation. Furthermore, the findings indicate that students have positive perspectives concerning their future work opportunities. It was found that the instrument subscales had Cronbach's alpha ranging from 0.864 to 0.919 , which is an indication of the excellent internal consistency of the scale. A moderate to strong association was formed between all the study variables (cognitive $=0.531$; technical $=0.576$; emotional $=0.537 ; \mathrm{p}<0.01$ ) listed in Table 2 when the coefficient $r$ was calculated using the $95 \%$ confidence interval.

According to Horn (2006), the task of improving senior high school students' employability in today's labor market, which is defined by the information revolution, ongoing technological innovation, globalization, and rearranged work procedures, has become formidable. The trends necessitate learners who are proficient in 21st-century skills, self-motivated, capable of working independently, capable of setting demanding personal objectives, and capable of quickly adapting to changing conditions. These skills include competence in math, technology, reading, writing, and reasoning; the capacity to use resources and information effectively; interpersonal skills; comprehend systems and grasp technology; and the flexibility to deal with change in the workplace (Aliazas et al., 2021). Career planning was found to be significant to high school students; individuals seek advice and information from a number of perspectives and professional supervision and direction to assist them with their career preparation (Witko et al., 2005). Sulistiani \& Yulianto (2019) also suggest using teaching factories, professional certification, and innovations to improve employability skills as a method of curriculum implementation. It is intended to 
Imelda G. Carada et./al Perceived Skills and Employability of Senior High School Graduates: Basis for Youth Employment Policy

make enough provisions for people to enter the field of competitive professional labor in accordance with set criteria.

Table 3. Regression Coefficients, Standard Errors, and Model Summary for the Presumed Influence of Perceived Skills to Employability of Senior High School Graduates

\begin{tabular}{|c|c|c|c|c|c|}
\hline \multirow[t]{2}{*}{ Antecedent } & \multicolumn{2}{|c|}{$\begin{array}{l}\text { Unstandardized } \\
\text { Coefficients }\end{array}$} & $\begin{array}{l}\text { Standardized } \\
\text { Coefficients }\end{array}$ & \multirow[t]{2}{*}{$\mathbf{t}$} & \multirow[t]{2}{*}{ Sig. } \\
\hline & $\mathbf{B}$ & Std. Error & Beta & & \\
\hline (constant) & 0.875 & 0.176 & & 4.976 & 0.000 \\
\hline Technical Skills & 0.437 & 0.073 & 0.394 & 5.998 & 0.000 \\
\hline Emotional Skills & $\begin{array}{l}0.264 \\
\end{array}$ & 0.070 & 0.248 & 3.782 & 0.000 \\
\hline$R^{2}=0.360$ & Adj. $R^{2}=0.356$ & $F=90.466$ & $p=0.000$ & $N=324$ & \\
\hline
\end{tabular}

Table 3 presents the coefficients of direct effects of the independent variables (cognitive, technical, and emotional skills) to the outcome variable (employability). Regression analysis revealed that two perceived skills factors significantly predict the senior high school graduates' employability at a $95 \%$ confidence interval. The regression analysis revealed that the strongest predictor of senior high school graduates' employability are technical skills $(\beta=0.437, p=0.000)$, and emotional skills $(\beta=0.264, p=0.000)$. It shows that a one-unit change in technical and emotional skills can result in a 0.437 and 0.264 -unit change in the employability of senior high school graduates, respectively. The two perceived skills contributed considerably to the regression model $(\mathrm{F}=90.466)$ and accounted for $36 \%$ of the variation in senior high school graduates' employability scores as revealed by the $\mathrm{R}^{2}$ values.

Being highly employable and ready for the market is linked to having an acceptable awareness of prospects. This link backs up Salape \& Cuevas' (2020) assertion that job seekers must be aware of available employment as well as what companies are seeking. They demonstrated this by researching all fields of work that they might be interested in, as employers value foresight. Likewise, Dimaunahan \& Panoy (2021) reiterates that the relationship between self-efficacy in gaining technical skills and graduation performance was discovered to be considerable. Students' performance was positively associated with their self-efficacy or belief in their ability to succeed in gaining technical skills unique to each subject. This suggests that the more the students' self-efficacy, the more likely they are to succeed in their jobs. In the study of McDonnall \& O'Mally (2012), aspects of early work experiences such as obtaining a job on one's own, having many jobs, and holding jobs for extended lengths of time were found to be connected with future employment outcomes.

\section{Conclusions}

In general, the current study's findings revealed that perceived skills among senior high school graduates were highly manifested in their daily activities. An individual will likely be employable based on the perceived skills. The three skills (cognitive, technical, and emotional) and the employability of senior high school graduates are moderate to strongly associate with one another. Further research found that technical and emotional skills are substantial employability indicators among senior high school graduates.

The study's findings have important implications for developing a successful youth employment policy. To properly address the mounting problem of unemployment, a collaborative effort involving the public and private sectors, as well as educators, is required. Learners should be exposed to suitable outcomes-based entrepreneurial activities, and teachers should be encouraged to take a fresh look at things. Future research should look into other factors that could help students enhance their job market abilities. Learners must understand that while applying for jobs or enrolling in a postsecondary institution, they must choose their themes intelligently. Teachers must continually remind their students of the precise skills required by today's job market in order for them to perform their assigned duties and successfully adopt the new frameworks. It is everyone's responsibility to prepare our students for the future. The execution of our cooperation approach is required because we must have a strong and unwavering commitment to work for the greater benefit of the majority, because we are all accountable for the greater good. 


\section{References}

1. Aliazas, J.C., Panoy, J.D., Del Rosario, A.P. \& Madrideo, J.V. (2021). Critical Success Factors of the Flexible Learning Delivery as Organizational Innovation of One State University in the Philippines. International Journal of Educational Management and Development Studies, Volume 2, Issue 3, pp. 61 - 77. https://doi.org/10.53378/348736

2. Bird, K. (2021). Philippines' COVID-19 Employment Challenge: Labor Market Programs to the Rescue. Adb.org._ https://blogs.adb.org/blog/philippines-covid-19-employment-challenge-labormarket-programs-to-rescue

3. BusinessWorld Online. (2021, June 24). Employers worried about SHS graduates' readiness for work. BusinessWorld Online. https://www.bworldonline.com/employers-worried-about-shsgraduates-readiness-for-work/

4. Cabrera, A. (2018) Job Opportunities in the Philippines retrieved from https://peopledynamics.co/job-opportunities-philippines/

5. Castro, E. A. (2014). Implications of Credentials, Employee Selection Process and HEI Quality on Graduate Employment Success: Employment Transition Patterns in the Labor Market of Batangas, Philippines. Review of Integrative Business and Economics Research,3(1), 284. http://sibresearch.org/uploads/3/4/0/9/34097180/riber_k14-153_303-320.pdf

6. Cecilio, A. (2019). BusinessMirror. BusinessMirror. https://businessmirror.com.ph/2019/02/01/isthere-a-job-waiting-for-senior-high-school-graduates/

7. CEICdata.com. (2018). Philippines Unemployed: Grade Completed: High School: Graduate. Ceicdata.com; CEICdata.com. Retrieve from: t.ly/yZXw

8. CNN Philippines (30 March 2021) Unemployment worsens with 4.2 million jobless in February PSA https://cnnphilippines.com/news/2021/3/30/PSA-unemployment-worsens-4.2-million-FilipinosFebruary.html

9. Conley, D. T., Drummond, K. V., De Gonzalez, A., Rooseboom, J., \& Stout, O. (2011). Reaching the Goal: The Applicability and Importance of the Common Core State Standards to College and Career Readiness. Educational Policy Improvement Center (NJ1).

10. Dimaunahan, J. M., \& Panoy, J. F. D. Academic Motivation and Self-Efficacy in Technical Skills as Correlates to Academic Performance. International Journal of Educational Management and Development Studies, 2(4), 72-89.

11. Horn, G. (2006). Education Solutions to Improve the Employability of Senior High School Learners. $\begin{array}{llll}\text { South African Journal } & \text { Education, } & \text { 26(1), }\end{array}$ https://www.ajol.info/index.php/saje/article/view/25059/91022

12. Leech, N. L., Barrett, K. C., \& Morgan, G. A. (2014). IBM SPSS for intermediate statistics: Use and interpretation. Routledge.

13. Lovasz , M. (2016). Systems Theory Framework: A Culturally Responsive Model for Career Guidance. National Career Development Association

14. https://associationdatabase.com/aws/NCDA/pt/sd/news_article/290948/_PARENT/CC_layout_detail s/false

15. Manusov, V., \& Spitzberg, B. (2008). Attribution theory. na.

16. McDonnall, M. C., \& O'Mally, J. (2012). Characteristics of early work experiences and their association with future employment. Journal of Visual Impairment \& Blindness, 106(3), 133-144.

17. Mocon-Ciriaco, C. (22 Jan 2018) DepEd defends SHS graduates' competence for employment retrieved from https://businessmirror.com.ph/2018/01/22/deped-defends-shs-graduates-competencefor-employment/

18. Moscoso, S., Salgado, J. F., \& Anderson, N. (2017). How do I get a job, what are they looking for? Personnel selection and assessment. An introduction to work and organizational psychology: An international perspective, 25-47.

19. Official Gazette (n.d) What is K12 Program? Retrieved from https://www.officialgazette.gov.ph/k12-old/ 
20. Omoth, T. (2020). The Top 13 Job Skills That Employers Are Looking for in the Future. TopResume; https://www.topresume.com/career-advice/top-professional-skills-for-resume

21. Orbeta Jr, A. C., Lagarto, M. B., Ortiz, M. K. P., Ortiz, D. A. P., \& Potestad, M. V. (2018). Senior High School and the Labor Market. Philippine Institute for Development Studies. Discussion Paper Series No. 2018-49. https://www.think-asia.org/bitstream/handle/11540/9526/pidsdps1849.pdf?sequence=1

22. Orbeta Jr, A. C., \& Potestad, M. V. (2020). On the Employability of the Senior High School Graduates: Evidence from the Labor Force Survey. Philippine Institute for Development Studies. $\begin{array}{llll}\text { Discussion } & \text { Paper } & \text { Series } & \text { No. }\end{array}$ https://pidswebs.pids.gov.ph/CDN/PUBLICATIONS/pidsdps2040.pdf

23. Patton, W., \& McMahon, M. (2014). Career development and systems theory: Connecting theory and practice (Vol. 2). Springer.

24. Philippine Star (30 September 2019) Companies still hesitant to hire $\mathrm{k} 12$ graduates https://cnnphilippines.com/news/2021/3/30/PSA-unemployment-worsens-4.2-million-FilipinosFebruary.html

25. Philippine Statistics Authority. (2021). Unemployment Rate in October 2021 is Estimated at 7.4 Percent. Psa.gov.ph. https://psa.gov.ph/content/unemployment-rate-october-2021-estimated-74percent

26. Salape, R. C., \& Cuevas, E. G. (2020). The link between career development learning and employability skills of senior high school students.

27. Salgado, J. F. (2017). Personnel selection. In Oxford Research Encyclopedia of Psychology.

28. Sulistiani, S., \& Yulianto, B. (2019). Employability Skills of Vocational Graduates: Implementation of Curriculum IQF Level 2. In 3rd International Conference on Education Innovation (ICEI 2019) (pp. 278-282). Atlantis Press.

29. Tuominen-Soini, H., Salmela-Aro, K., \& Niemivirta, M. (2012). Achievement goal orientations and academic well-being across the transition to upper secondary education. Learning and individual differences, 22(3), 290-305.

30. Wan, X., Wang, W., Liu, J., \& Tong, T. (2014). Estimating the sample mean and standard deviation from the sample size, median, range and/or interquartile range. BMC medical research methodology, 14(1), 1-13.

31. Witko, K., Bernes, K.B., Magnusson, K., \& Bardick, A.D. (2005). Senior high school career planning: what students want. Journal of Educational Enquiry, Vol. 6, No. 1, 2005

32. Yee, J. (7 April 2018) SPECIAL REPORT: Jobs a hit or miss for senior high school graduates https://newsinfo.inquirer.net/980738/special-report-jobs-a-hit-or-miss-for-senior-high-schoolgraduates\#ixzz6v8QTeSTa 